Jurnal Professional FIS UNIVED Vol. 3 No.1 Juni 2016

\title{
KONSTRUKSI MEDIA TERHADAP TRANSGENDER
}

\author{
Oleh: \\ FITRI MELIYA SARI \\ Dosen Prodi Ilmu Komunikasi Penyiaran Islam Fakultas Dakwah \\ Universitas Serambi Mekkah
}

\begin{abstract}
This research was a study conducted on transgender as one of the media spotlight. This study aimed to describe how the media portrays the existence of transgender in Indonesia through media. In this case the researchers looked at the cases of Dena Rachman. Results showed that there was particular justification of media in portraying negatively the behavior of people who become transgender or the like. The portrayal makes people against for the decision and behavior taken by Dena Rachman. Changing the male identity to be a female is very unusual. Especially for those who think that identity is inherent and unchangeable. Yet this identity is socially constructed and liquid. Dena Rachman'a changing reinforces the notion that gender is only two, namely men and women.
\end{abstract}

\section{Keywords: Transgender, Mass Media, Social Construction.}

\section{PENDAHULUAN}

Transgender masih sesuatu yang dianggap tabu di dunia, terlebih di Indonesia. Transgender adalah sesuatu yang meliputi banyak orang dengan identitas yang spesifik. Intinya, seseorang yang beridentitas transgender memiliki gender dengan jenis kelamin yang berbeda secara biologis. Ada perbedaan bentuk transgender, diantaranya cross-dresser, drag queens, drag kings, wanita yang maskulin, dan laki-laki yang gemulai (NLGJA, 2008). Hanya beberapa negara yang sudah mulai melegalkan atau mengakui adanya transgender, seperti Jerman, India dan beberapa negara lainnya. Indonesia memiliki semboyan "Bhineka Tunggal Ika" yang artinya walaupun berbeda tetapi satu jua namun semboyan ini tidak mewakili keberadaan kaum LGBT (Lesbian, Gay, Biseksual, dan Transgender). Perbedaan di sini hanya dimaksudkan kepada perbedaan suku dan ras, namun orientasi seksual tidak termasuk di dalamnya.

Lahirnya konsep LGBT terjadi pada saat adanya revolusi seksual tahun 1960 dan berkembang pada tahun 1990-an. Di Indonesia sendiri identitas tentang homoseksual muncul pada awal abad 20 (Dédé Oetomo dan Khanis Suvianita, 2013). Dan kaum LGBT memiliki symbol yang dipahami secara internasional berupa bendera pelangi dan segitiga merah muda. Di Indonesia sendiri terdapat suku yang mengakui adanya Transgender atau anggota LGBT lainnya dengan wajar, seperti Bissu di Bugis atau dalam seni tradisional Lubruk. Tetapi masih banyak juga masyarakat yang tidak mengetahui hal ini karena tidak tersaji dalam Bahasa Indonesia (Rachmah Ida, 2010).

Dalam kalimat pertama Deklarasi Universal Hak-Hak Asasi Manusia 
(Universal Declaration of Human Rights), Dewan HAM PBB mengatakan "Setiap manusia dilahirkan merdeka dan mempunyai hak dan martabat yang sama...". Dewan HAM PBB mensahkan revolusi persamaan hak setiap manusia dilahirkan bebas dan memperoleh hanya tanpa ada diskriminasi. Resolusi PBB ini merupakan yang pertama, secara spesifik mengangkat isu pelanggaran HAM berdasarkan orientasi seksual dan identitas gender (Rahayu Lestari, 2014).

Terdapat stigma negative terhadap keberadaan kaum Transgender, hal ini dikarenakan konstruksi dari media massa yang ada. Media massa saat ini sangat dapat memberikan pengaruh kepada masyarakat. Salah satu fungsi media massa adalah memberikan informasi kepada masyarakat. Namun informasi yang diberikan belakangan ini sangat sarat makna. Di mana ada pihak-pihak tertentu yang dapat memberikan konstruksi atau penggambaran tentang sesuatu kebenaran yang ada.

Media massa membentuk pencitraan tertentu kepada khalayak masyarakat tentang Transgender dan sejenisnya. Media massa sangat berpengaruh dalam memberikan gambaran atau pencitraan dari satu masyarakat atau kelompok tertentu agar dapat diterima di khalayak ramai. Dan stereotype yang melekat pada kaum Transgender dan sejenisnya adalah merekamereka yang dianggap menyimpang dari norma yang berlaku.

Pencarian identitas membuat tidak sedikit juga masyarakat yang merasakan bahwa dirinya bukanlah berjenis kelamin tertentu sehingga dia merubah jenis kelaminnya dengan operasi dan siap menghadapi anggapan negative dari masyarakat tentang tindakan yang meraka lakukan. Kasus ini terjadi pada artis Dorce Gamalama beberapa tahun silam. Dan belakangan ini masyarakat juga dikagetkan dengan adanya Transgender baru, yaitu
Dena Rachman. Dena Rachman alias Renaldy adalah mantan artis cilik yang telah merubah jenis kelaminnya dari laki-laki menjadi perempuan. Terjadi krisis identitas di dalam diri Dena Rachman.

Dena begitu biasa ia dipanggil saat ini, terlahir sebagai lelaki merasa ada yang salah pada dirinya. Dia merasa dirinya sebagai perempuan yang terjebak di tubuh lelaki. Dena mengatakan bahwa dia awalnya binggung dan bahkan membenci dirinya sendiri karena hal tersebut. Karena identitas yang seharusnya ia milili tidak sesuai dengan kenyataan. Disitulah terjadi negosiasi identitas, di mana pada tahun 2005 dia mulai berani mengubah penampilannya sebagai perempuan. Namun dia belum terlalu yakin untuk melakukan operasi penggantian jenis kelamin. Baru pada saat dia berumur 25 tahun, dia yakin melakukan operasi dan berubah sepenuhnya menjadi perempuan.

Penggambaran media massa terhadap kaum Transgender sebagai kaum yang dianggap menyimpang masih terjadi. Media massa Barat memiliki peran utama dalam penyebaran informasi secara global dengan stereotype yang diskriminatif terhadap Transgender menyebabkan masyarakat menghilangan hak-hak kaum LGBT untuk mengekspresikan diri serta akses politik tertentu. Konstruksi media menyebabkan ketidakadilan sosial marak terjadi, dan media massa bertanggung jawab atas pemberitaannya.

Dalam perkembangannya, saat ini banyak sekali muncul konstruksi baru oleh media melalui film atau acara lainnya yang bertema LGBT. Tetapi masih kuatnya hegemoni dan dominasi yang menentang kaum ini belum bisa mengubah pandangan masyarakat. Terlebih lagi dengan maraknya kasus kekerasan yang dialami atau dilakukan oleh kaum ini membuat stereotype negative semakin melekat. 
Pencitraan negative tersebut semakin diperkuat dengan munculnya reality show Be A Man. Di dalam acara tersebut digambarkan ada beberapa waria yang dilatih sampai benar-benar menjadi laki-laki sejati; berpenampilan dan berkelakuan maskulin. Hal ini menunjukkan bahwa dalam masyarakat Indonesia sosok laki-laki semacam inilah yang bisa diterima sedangkan yang lain (kaum waria tersebut) tidak. Transgender merupakan suatu gejala ketidakpuasan seseorang karena merasa tidak adanya kecocokan antara bentuk fisik dan kelamin dengan kejiwaan ataupun adanya ketidakpuasan dengan alat kelamin yang dimilikinya.

Transgender istilah umum bagi orang-orang yang identitas gender, ekspresi gender, atau Perilaku tidak sesuai dengan yang biasanya terkait dengan seks yang mereka ditugaskan saat lahir (American Psychological Association, 2002). Identitas gender mengacu pada perasaan internal seseorang "makna menjadi" laki-laki, perempuan, atau sesuatu yang lain. Ekspresi gender merujuk pada cara seseorang berkomunikasi dengan orang lain melalui identitas jender melalui perilaku, pakaian, gaya rambut, suara, atau karakteristik tubuh. "Trans" kadang-kadang digunakan sebagai singkatan untuk "transgender". Sementara transgender adalah umumnya istilah yang baik untuk digunakan, tidak semua orang penampilan atau perilaku yang merupakan gender tidak sesuai akan mengidentifikasi sebagai orang trans gender. Cara cara orang transgender yang dibicarakan dalam budaya populer, akademisi, dan ilmu pengetahuan selalu berubah, terutama sebagai kesadaran, pengetahuan, dan keterbukaan individu tentang orang-orang transgender dan pengalaman mereka bertambah.

Namun stereotype negative ini tidak menghalangi mantan artis cilik Dena Rachman alias Renaldy untuk menjadi seorang transgender. Butuh pergulatan panjang dalam dirinya untuk mengambil keputusan dengan melakukan operasi. Banyak pertimbangan yang dipikirkan sehingga akhirnya dia melakukan operasi tersebut. Melihat kasus Transgender yang dilakukan Dena Rachman dan pemberitaannya di media massa menimbulkan pertanyaan bagaimana konstruksi media dalam merepresentasikan perubahan yang dilakukan oleh Dena Rachman?

\section{KONSEP TEORITIS}

\section{Transgender Dena Rachman}

Transgender adalah istilah yang digunakan untuk mendeskripsikan orang yang melakukan, merasa, berpikir atau terlihat berbeda dari jenis kelamin yang ditetapkan saat mereka lahir. "Transgender" tidak menunjukkan bentuk spesifik apapun dari orientasi seksual orangnya. Orangorang transgender dapat saja mengidentifikasikan dirinya sebagai heteroseksual, homoseksual, biseksual, panseksual, poliseksual, atau aseksual. Definisi yang tepat untuk transgender tetap mengalir, namun mencakup:

- "Tentang, berkaitan dengan, atau menetapkan seseorang yang identitasnya tidak sesuai dengan pengertian yang konvensional tentang gender laki-laki atau perempuan, melainkan menggabungkan atau bergerak di antara keduanya."

- "Orang yang ditetapkan gendernya, biasanya pada saat kelahirannya dan didasarkan pada alat kelaminnya, tetapi yang merasa bahwa deksripsi ini salah atau tidak sempurna bagi dirinya."

"Non-identifikasi dengan, atau nonrepresentasi sebagai, gender yang diberikan kepada dirinya pada saat kelahirannya" (dalam artikel Transgender 
"Manusia Keragaman dan

Kesetaraannya", 2009).

Adapun penyebab terjadinya transgender dapat diakibatkan 2 faktor, yaitu:

a. Faktor bawaan (hormon dan gen). Faktor genetik dan fisiologis adalah faktor yang ada dalam diri individu karena ada masalah antara lain dalam susunan kromosom, ketidakseimbangan hormon, struktur otak, kelainan susunan syaraf otak.

b. Faktor lingkungan. Faktor lingkungan di antaranya pendidikan yang salah pada masa kecil dengan membiarkan anak laki-laki berkembang dalam tingkah laku perempuan atau sebaliknya, pada masa pubertas dengan homoseksual yang kecewa dan trauma, trauma pergaulan seks dengan pacar, suami atau istri.

$$
\text { Pada hakikatnya, masalah }
$$

kebingungan jenis kelamin atau yang lazim disebut juga sebagai gejala transseksualisme ataupun transgender merupakan suatu gejala ketidakpuasan seseorang karena merasa tidak adanya kecocokan antara bentuk fisik dan kelamin dengan kejiwaan ataupun adanya ketidakpuasan dengan alat kelamin yang dimilikinya. Dena Rachman alias Renaldy Rachman terlahir sebagai seorang laki-laki. Dia sukses menjadi salah satu acara anak-anak "Krucil (Kru Cilik)" yang ditayangkan di SCTV pada era 90-an. Dena (Renaldy) Rachman lahir di Jakarta, 30 Agustus 1987 ini juga pernah bermain di sinetron Misteri Gunung Merapi yang pernah membesarkan namanya waktu itu. Sejak kecil, Dena merasakan ada yang berbeda pada dirinya, dia lebih senang dengan mainan perempuan daripada lakilaki.

Dari sejak kecil Dena lebih kemayu dan gemulai. Dia merasa dirinya sebagai perempuan yang terjebak di tubuh lelaki. Dena mengatakan bahwa dia awalnya binggung dan bahkan membenci dirinya sendiri karena hal tersebut. Karena identitas yang seharusnya ia miliki tidak sesuai dengan kenyataan. Disitulah terjadi negosiasi identitas, di mana pada tahun 2005 dia mulai berani mengubah penampilannya sebagai perempuan. Namun dia belum terlalu yakin untuk melakukan operasi penggantian jenis kelamin. Baru pada saat dia berumur 25 tahun, dia yakin melakukan operasi dan berubah sepenuhnya menjadi perempuan.

Pada umumnya seseorang yang berbeda atau tidak normal dianggap berbeda dan tidak bisa masuk dalam kelmpok yang sama, karena meraka dianggap memiliki perbedaan yang membuat orang memandanya itu tidak layak untuk hidup berdampingan. Biasanya mereka dikucilkan dari lingkungan dan dijadikan bahan pembicaraan atau dicemooh oleh masyarakat sekitar. Bahkan mereka dianggap dapat membawa pengaruh negative untuk lingkungan masyarakat. Seorang transgender yaitu dalam kasus Dena memiliki kendala seperti diskriminasi dan bullying dari masyarakat.

\section{Pembentukan Identitas}

Identitas adalah konsep mengenai diri. Identitas tidak hanya sekedar "siapa saya?". Identitas menjadi masalah yang sangat komplek tentang bagaimana pemahaman seseorang mengenai apa, siapa dan bagaimana dirinya? Identitas berada dalam konstruksi sosial dan dapat menyebabkan adanya "kriris identitas". Krisis ini terjadi karena orang-orang berusaha mencari posisi mereka yang stabil di dunia. Identitas menjadi penghubung dengan lingkungan. Dalam buku Teori Komunikasik karangan Litterjohn, dikatakan bahwa kita memperoleh identitas dalam bagian yang lebih luas dari konstruksi yang menawarkan identitas itu dari berbagai kelompok sosial di mana kita menjadi 
bagian keluarga, masyarakat, subkelompok budaya, dana ideology dominan. Di mana hal ini berarti bahwa identitas kita selalu ada dalam proses pembentukan, sebagaimana kita merespons kontekskonteks dan situasi di sekeliling kita (Littejohn, 2012).

Menurut Michael Hecht dan koleganya, identitas adalah "kode" yang mendefinisikan keanggotaan dalam komunitas yang beragam kode-kode yang terdiri dari symbol-simbol seperti bentuk pakaian, dan kepemilikan, dan kata-kata seprti deskripsi diri atau benda yang biasanya anda katakan dan makna yang anda dan orang lain hubungkan terhadap benda-benda tersebut.

Hecht memperkenalkan 4 dimensi untuk menguraikan identitas yaitu:

1. Tingkatan pertama, personal layer yang terdiri dari rasa akan keberadaan diri anda dalam situasi sosial.

2. Tingkatan kedua, enactmen layer atau pengetahuan orang lain tentang diri anda berdasarkan pada apa yang anda lakukan, apa yang anda miliki, dan bagaimana anda bertindak. Penampilan anda adalah symbol-simbol aspek yang lebih mendalam tentang identitas anda serta orang lain akan mendefinisikan dan memahami anda melalui penampilan tersebut.

3. Tingkatan yang ketiga adalah relational atau siapa diri anda dalam kaitannya dengan individu lain. Identitas dibentuk dalam interaksi anda dengan mereka.anda dapat melihat dengan sangat jelas identitas hubungan ketika anda merujuk diri anda secara spesifik sebagai mitra hubunga, seprti ayah, suami, ibu, rekan kerja.

4. Tingkatan keempat adalah tingkatan komunal yang diikat pada kelompok atau budaya yang lebih besar.Tingkat identitas ini sangat kuat dalam banyak budaya asia.

Dalam teori identitas ada juga teori negosiasi identitas yang diperkenalkan oleh Stella Ting Toomey mengeksplorasi caracara dimana identitas di negosiasi dalam interaksi dengan orang, terutama dalam berbagai budaya. Ting Toomey memfokuskan pada identitas etnik dan kebudayaan, terutama negosiasi yang terjadi ketika kita berkomunikasi di dalam dan diantara kelompok-kelompok kebudayaan.

Ting Toomey memberikan 3 landasan dasar dalam teori negosiasi identitas yaitu: pertama, pengetahuan (knowledge) yaitu pemahaman akan pentingnya identitas etnik dan kemampuan melihat apa yang penting bagi orang lain. Artinya mengetahui sesuatu tentang identitas kebudayaan dan mampu melihat segala perbedaan. Kedua, kesadaran (mindfulness) yaitu secara sederhana berarti secara biasa dan teliti untuk menyadari. Hal ini berarti kesiapan berganti ke perspektif baru. Ketiga, kemampuan (skill) yaitu kemampuan untuk menegoisasi identitas melalui observasi yang teliti, menyimak,empati, kepekaan non verbal, kesopanan dan kolaborasi.

Struart Hall beranggapan bahwa identitas adalah suatu konstruksi yang luwes, sebuah proses bukan hanya mengada (being) tetapi juga menjadi (becoming) yang mendasari perbedaan mendasar antara "kita ini siapa" dan "kita ini menjadi apa". Proses "becoming" ini pun terjadi terus menerus, tergantung oleh keadaan sosial, budaya, ruang dan tempat, dan lain-lainnya (Rutherford, 1990). Identitas adalah masalah posisi, bukan esensi dan bersifat cair. Identitas juga berkaitan dengan konsep representasi, menurut Hall (1996) identitas adalah perkara merepresentasikan diri.

Identitas merupakan konstruksi sosial secara keseluruhan dan tidak bisa berada di luar representasi kultural. Identitas 
meliputi bagaimana seseorang melihat dirinya sendiri dan bagaimana orang lain melihat orang itu. Untuk dapat membedakan (dan juga 'menyamakan') seseorang dengan orang lainnya, manusia diposisikan menjadi sebuah 'subjek' - dalam hal ini, "gendered subject" (Barker, 2004).

Tidak jauh berbeda dengan Hall, Butler (2006) dalam bukunya Gender Trouble mengatakan identitas terbentuk secara performatif melalui berbagai ekspresi yang selama ini dianggap sebagai hasilnya. "Gender identity appears primarily to be the internalization of a prohibiton that proves to be formative of identity" (Butler, 2006). Butler juga mengatakan bahwa tidak ada identitas jender yang asli, semua dibentuk melalui ekspresi dan pertunjukan yang terus diulang hingga membentuk identitas gender. Sehingga teori ini dapat menjadi titik tolak dalam menkaji perubahan identitas yang dilakukan oleh Dena Rachman.

\section{Teori Queer}

Queer dapat diartikan sebagai sesuatu yang buruk, menyimpang, dan tidak benar dan sekarang digunakan sebagai pandangan yang mendasari dukungan atas kaum LGBT. Teori Queer berpandangan tidak ada orientasi seksual yang bersifat natural, dengan demikian tidak ada pula orientasi seksual yang menyimpang yang merupakan teori identitas tanpa seksualitas.

Queer pada abad 19 diidentik dengan homoseksual. Queer dijadikan sebagai istilah "payung" untuk identifikasi seksual marginal diri dan di lain waktu digunakan untuk menggambarkan model teori dasar yang telah dikembangkan dari studi mengenai kebiasaan gay dan lesbian. Namun, istilah queer sendiri masih dalam proses pembentukan, sehingga belum mempunyai suatu pemahaman yang tepat. Disinilah istilah queer justru memperlihatkan keelastisitasnya dan ini menjadi karakteristiknya. Menurut Michel
Faucaults seksualitas bukanlah sebuah atribut khusus personal, tetapi sebuah kategori kultural yang ada, dan itu sebagai efek dari kekuasaan. Pemikiran Foucault ini menjadi bagian penting dalam perkembangan lesbian dan gay, serta aktivitas dan pengetahuan queer.

Dalam bukunya berjudul Gender Trouble: Feminism and the Subversion of Identity (2006), Butler mengelaborasi argumen Foucaults tentang opresi kuasa dan perlawanan untuk memperlihatkan bagaimana identitas yang termarginalkan muncul secara komplek bersamaan dengan rezim identifikasi tersebut, yang dicari sebagai penanding. Teori Queer Judith Butler berawal dari identitas merupakan sebagai suatu free-floating, berkaitan dengan tindak performatif individu dan tidak berkaitan dengan suatu esensi dalam diri individu. Butler menolak prinsip identitas yang memiliki awal dan akhir. Dia juga menolak pandangan seks (male/female) sebagai penentu dari gender (masculine/feminine), dan gender sebagai penentu sexual orientation. Identitas tidak berhubungan dengan seks dan gender, berubah-ubah dan tidak stabil.

Butler menggambarkan gender sebagai suatu fiksi budaya, suatu efek performatif dari tindakan-tindakan berulangulang. Menurutnya, tidak ada gender yang otentik, karena tidak ada identitas gender di balik ekspresi-ekspresi gender. Identitas merupakan tampilan-tampilan performatif yang didasari oleh seluruh ungkapan dan sebagai hasil tampilan-tampilannya. Performativitas ini menjadi perdebatan. Perdebatan tentang performativitas menempatkan sebuah tekanan denaturalisasi pada sex, gender, sexualitas, tubuh dan identitas. Butler menegaskan bahwa kategori identitas cenderung menjadi rezim pengatur. Baik identitas sebagai kategori normal struktur yang opresif atau menekan, maupun 
identitas sebagai kumpulan poin-poin untuk suatu kontestasi yang membebaskan dari seluruh tekanan.

Butler mengatakan tidak ada kondisi alamiah bagi manusia selain penampakan tubuhnya. Seks, gender, maupun orientasi seksual adalah konstruksi sosial. Hal ini dapat dicontohkan melalui fenomena transgender. Seorang yang telah melakukan transgender, yang diasumsikan telah 'merubah' kondisi alamiahnya. Misalnya seorang pria yang merasa beridentitas feminine, mengubah jenis seksnya menjadi tubuh perempuan. Pertanyaannya adalah, setelah seks sebagai fakta biologis tersebut diubah menjadi yang sebaliknya, bukankah perubahan ini menentukan keabsahan dari individu tersebut untuk bertindak sesuai dengan ketentuan the fixed rules atas seks, gender, dan orientasi seksual. Hal ini yang dilakukan oleh Dena Rachman, dia merasakan bahwa sebenarnya ada pergolakan dalam dirinya yang menyatakan dia seorang perempuan yang terjebak dalam tubuh laki-laki.

\section{PEMBAHASAN \\ Perkembangan dan Pembentukan Identitas}

Identitas terkadang menjadi sesuatu yang sangat dipermasalahkan ketika seseorang merasakan dirinya tidak sesuai dengan apa yang terlihat. Terlebih menurut Guantlett (2002) format identitas dalam masyarakat itu tidak hanya dibentuk oleh individu, melainkan lebih banyak dibentuk dan dipaksakan oleh kekuasaan, baik dalam bentuk legal formal yang dilakukan negara, maupun yang dilakukan oleh masyarakat di sekitarnya melalui norma dan nilai-nilai idealism yang dipegang oleh masyarakat (Rachmah Ida, 2010). Pemikiran Butler tentang "performativity" adalah tentang apa yang katakan atau lakukan bersifat konstitutif. Seperti mengisi formulir pada kolom jenis kelamin, menurut Butler itu bukan "menginformasikan" jenis kelamin kita, melainkan kita "membentuk" jenis kelamin.

Dena mempunyai identitas pribadi yang dibentuk dari keluarga dan lingkungan sosial merupakan seorang lelaki. Identitas yang diperoleh sejak lahir dan terbentuk di dalam lingkungan sosial. Namun terjadi negosiasi identitas dalam dirinya ketika dia merasa bahwa identitasnya tersebut salah. Dia merasa bahwa seharunya ia memiliki jenis kelamin perempuan atau terlahir sebagai perempuan bukan lelaki. Meskipun transgender merupakan salah satu kelainan medis. Tetapi transgender bisa saja terjadi akibat pembentukan identitas atau negosiasi identitas dalam lingkungan sosial yang membentuk rasa percaya diri bahwa dia bukan seorang lelaki melainkan perempuan. Kebanyakan orang yang mengalami transgender binggung akan jati diri mereka yang sebenarnya. Apalagi dilihat dari segi agama dan lingkungan. Itu merupakan hal yang sangat tabu. Terlebih di Indonesia. Meskipun ada beberapa negara besar seperti Amerika dan Australia yang sudah mengizinkan warga negaranya melakukan operasi perubahan kelamin.

Namun Butler menegaskan bahwa gender atau seksualitas adalah "struktur imitatif, atau akibat proses imitasi, pengulang-ulangan dan performativitas." Konsep "performativitas" memang sentral dalam pemikiran Butler. Butler meminjam konsep ini dari teori sastra yang mangkategorikan makna menjadi dua; yaitu konstantif dan performatif. Makna konstantif adalah berita atau ekspresi, sedangkan perfomatif adalah makna yang membentuk kenyataan. Penegasan "saya laki-laki" disamping bersifat ekspresif, yaitu "memberitahukan bahwa jenis kelamin saya laki-laki," juga bersifat performatif, yaitu "saya laki-laki, oleh karena itu juga harus 
bertindak dengan norma-norma laki-laki." Jadi, ada efek konstitutif, pembentuk kenyataan, dalam performativitas ini.

Awalnya keluarga tidak setuju dengan tidakan dari anak kedua dari empat bersaudara ini. Terlebih lagi di mana dia adalah anak laki-laki satu-satunya dalam keluarga, membuat keluarganya sampai mengusir dan tidak mau mengakuinya sebagai anak. Keluarga Dena menganggap keputusan yang dilakukannya keliru dan berlawanan dengan agama dan norma yang ada. Kesenjangan keluarga pun terlihat jelas, di mana keluarga harusnya menjadi tempat di mana kita saling mendukung tetapi keluarga juga terikat norma dan nilai yang ada. Butuh waktu yang lama untuk keluarga dapat menerima keputusan yang diambil oleh Dena. Tidak hanya dari segi agama, akan banyak sekali orang yang pro atau kontra terhadap tindakan ini. Namun akhirnya keluarga dapat menerima keputusan Dena dan memberikan dukungan kepadanya karena melihat Dena nyaman dengan apa yang dirasakan dan dilakukannya. Tidak hanya itu saja, keluarga juga melihat Dena lebih bahagia sebagai wanita.

Pencitraan negatif atau stereotipe oleh media massa dan pemahaman masyarakat dua hal yang tidak bisa dilepaskan. Sekali media massa menanamkan suatu stereotipe tertentu dan masyarakat mengamininya, maka hal ini yang akan diteruskan ke generasi selanjutnya. Dari pemahaman masyarakat yang seperti ini muncul dorongan agar media massa mencitrakan hal serupa seterusnya dan hal ini menjadi lingkaran hitam di mana transgender atau sejenisnya tidak akan pernah terlepas dari anggapan negatif masyarakat dan institusi media massa.

Padahal gender, bahkan seks, bagi Judith Butler merupakan "pertunjukan", bukan esensi, atau ekspansi dari seks yang ada pada tubuh. Bagi Butler, gender adalah drag, atau seperti drag, yaitu adanya transgender seperti Dena Rachman dan lainnya menguji dan membuktikan bahwa mereka telah menghasilkan femininitas yang sebenarnya. Dalam pertunjukan itu, para juri telah mengetes dan mengesahkan kehalusan kulit, kegemulaian gerak, kelembutan suara. Gender adalah "pertunjukan" atau hasil pertunjukan seperti itu. Para jurinya adalah teman, orang tua, media dan sebagainya.

Penggambaran tentang perubahan yang dilakukan oleh Dena yang diberitakan oleh media membuat masyarakat sadar bahwa tidak semua masyarakat bisa memiliki kehidupan norma sejak lahir. Terjadi perubahan-perubahan yang membuat kita semakin menyadari siapa diri kita dan apa yang kita. Pemberitaan tersebut bisa menjadi dua sisi mata uang, disatu sisi masyarakat akan dapat menerima bahwa ada orang-orang seperti Dena Rachman yang merasakan terjebak dalam tubuh yang bukan dirinya. Namun disisi lain pemberitaan ini akan semakin memberikan steriotipe negative terhadap para transgender. Bahwa mereka tidak layak ada karena menyalahi aturan yang ada. Terlebih lagi hanya beberapa Transgender yang berprestasi seperti Dena Rachman. Banyak berita yang memuat tentang sisi negative Transgender seperti yang baru-baru ini terjadi terhadap Mayang Prasetyo, trasgender Indonesia korban mutilasi di Australia.

Dan penggambaran ini semakin menguatkan bahwa transgender atau sejenisnya tidak baik. Terlebih juga menguatkan bahwa gender yang alami itu hanya laki-laki dan perempuan. Tindakan operasi kelamin yang dilakukan oleh Dena Rachman semakin membuktikan bahwa tidak ada gender selain perempuan atau lakilaki, sehingga membuat dia merubah kelaminnya meski harus melewati 
pergulatan yang sangat panjang di dalam dirinya sendiri serta juga di keluarga. Terjadi naturalisasi di mana hanya ada dua jenis kelamin yaitu perempuan dan laki-laki, tidak hanya itu penaturalisasian juga terjadi dalam hal kekerasan yang dialami atau bullying yang terjadi atas tindakan Dena Rachman dalam merubah penampilannya.

Butler mengatakan bahwa identitas adalah sesuatu yang cair dan tidak berkaitan dengan gender atau seks. Hal ini sangat bertentangan dengan apa yang terjadi saat ini. Masih banyaknya masyarakat yang memandang aneh dan tidak menyukai perbuatan yang dilakukan Dena Rachman dan transgender lainnya. Melekatnya anggapan bahwa identitas itu tidak cair bahkan tetap menjadikan masyarakat hanya akan mengakui dua gender atau jenis kelamin. Bahkan jika dilihat dari tindakannya, Dena Rachman pun merupakan bagian masyarakat yang hanya mengakui adanya dua gender.

\section{PENUTUP}

\section{Kesimpulan}

Transgender bisa terjadi karena ada dua faktor yaitu biologis dan lingkungan. Pada kasus Dena dia meraskan bahwa faktor biologis yang sangat mendukungnya untuk menjadi transgender. Dena mengalami pergulatan yang sangat lama dalam memutuskan untuk merubah jenis kelaminnya menjadi perempuan, tidak hanya itu awalnya keluarga juga melakukan penolakan atas tindakannya. Meskipun kini akhirnya keluarga mendukungnya. Dukungan keluarga membuatnya semakin yakin akan keputusannya. Media massa memberikan gambaran yang negatif terhadap tindakan atau tingkah masyarakat yang menjadi transgender atau sejenisnya. Penggambaran tersebut membuat masyarakat menjadi kontra atas tindakan yang dilakukan oleh Dena Rachman. Merubah identitas dari laki-laki menjadi perempuan merupakan hal yang sangat tidak biasa. Terlebih bagi yang berpikir bahwa identitas itu melekat dan tidak berubah. Padahal identitas tersebut merupakan hasil konstruksi sosial dan cair. Namun melihat perubahan yang dilakukan Dena Rachman semakin menguatkan pendapat bahwa gender hanya ada dua, yaitu laki-laki dan perempuan.

\section{Saran}

Media harus bisa lebih bijak dalam menggambarkan LGBT. Jangan memuat tentang segi negatif tetapi harusnya lebih memberikan edukasi kepada masyarakat tentang keberadaan Transgender dan lainnya agar mereka juga memiliki hak dalam bersuara dan berekspresi seperti lainnya.

\section{DAFTAR PUSTAKA}

\section{Buku:}

Annamarie Jagose. (1996). Queer Theory: An Introduction. New York: New York University Press.

Chris Barker. (2004). Cultural Studies: Teori dan Praktik. Yogyakarta: PT Bentang Pustaka.

Jonathan Rutherford (ed). (1990). Identity: Community, Culture, Difference. London: Lawrence and Wishart.

Judith Butler. (2006). Gender Trouble. New York dan London: Raoutledge.

Lexy J Moleong. (2006). Metodologi

Penelitian Kualitatif. Bandung:

Remaja Rosdakarya.

Stephen W. Littlejohn dan Karen A. Foss. (2012). Teori Komunikasi Edisi 9 (terj.). Jakarta: Penerbit Salemba Humanika.

Stuart Hall. (1996). Who Needs Identity? Dalam: S. Hall \& P. Du Gay (eds). 
Questions of Cultural Identity. London: Sage.

\section{Jurnal:}

Dédé Oetomo dan Khanis Suvianita, (2013). Hidup Sebagai LGBT di Asia: Laporan Nasional Indonesia (Tinjauan dan Analisa Partisipatif tentang Lingkungan Hukum dan Sosial bagi Orang dan Masyarakat Madani Lesbian, Gay, Biseksual dan Transgender (LGBT)).

Juwilda. (2010). Transgender "Manusia Keseragaman dan Kesetaraan”. Artikel Ilmiah Universitas Sriwijaya.

NLGJA. (2008). National Lesbian \& Gay Journalists Association: Stylebook Supplement on LGBT Terminology. Stylebook Supplement.

Rachmah Ida. (2010). Respon Komunitas Waria Surabaya Terhadap Konstruk Subyek Transgender di Media Indonesia. Jurnal Ilmiah Vol 23, No 3.

Rahayu Lestari. (2014). Upaya Australian Marriage Equality Dalam Perubahan Kebijakan Same Sex Marriage Di Australia. EJournal Hubungan Internasional, 2014, 2(1): 111-122.

\section{Website:}

Fei. (2013). Meski Berat Keluatga Meluluskan Dena Rachman Operasi Kelamin.

http://showbiz.liputan6.com/read/617 980/meski-berat-keluargameluluskan-dena-rachman-operasikelamin. Diunduh 11 Oktober 2014, Jam 17.07.
Komario Bahar. (2013). Kisah Dena Rachman Yang Penah Ingin Mati. http://hot.detik.com/read/2013/06/07/ 145233/2267181/230/kisah-denarachman-yang-pernah-inginmati?hd771104bcj. Diunduh 11 Oktober 2014, Jam 17.20.

Tempo. (2013). Transgender Dena Rachman Datangi Psikolog. http://www.tempo.co/read/news/201 3/06/14/219488253/. Diakses 14 September 2013.

Wisnu Agung Prasetyo. (2013). Dena Rachman Merasa Berbeda Sejak Kecil. http://www.tempo.co/read/news/201 3/06/14/219488202/Dena-RachmanMerasa-Berbeda-Sejak-Kecil. Diunduh 11 Oktober 2014, Jam 17.14. 